"Assessing the level of competitiveness of the insurance sector during economic crises: The example of Ukraine"

\begin{tabular}{|c|c|}
\hline \multirow{5}{*}{ AUTHORS } & Iryna Tsymbaliuk (D) \\
\hline & Nataliia Pavlikha (D) \\
\hline & Olena Zelinska (iD) \\
\hline & Alisa Ventsuryk (iD) \\
\hline & Anna Radko (i) \\
\hline ARTICLE INFO & $\begin{array}{l}\text { Iryna Tsymbaliuk, Nataliia Pavlikha, Olena Zelinska, Alisa Ventsuryk and Anna } \\
\text { Radko (2021). Assessing the level of competitiveness of the insurance sector } \\
\text { during economic crises: The example of Ukraine. Insurance Markets and } \\
\text { Companies, 12(1), 72-82. doi:10.21511/ins.12(1).2021.07 }\end{array}$ \\
\hline DOI & http://dx.doi.org/10.21511/ins.12(1).2021.07 \\
\hline RELEASED ON & Tuesday, 28 December 2021 \\
\hline RECEIVED ON & Tuesday, 05 October 2021 \\
\hline \multirow[t]{2}{*}{ ACCEPTED ON } & Thursday, 23 December 2021 \\
\hline & $(\mathrm{ccc}) \mathrm{EY}$ \\
\hline LICENSE & $\begin{array}{l}\text { This work is licensed under a Creative Commons Attribution } 4.0 \text { International } \\
\text { License }\end{array}$ \\
\hline JOURNAL & "Insurance Markets and Companies" \\
\hline ISSN PRINT & $2616-3551$ \\
\hline ISSN ONLINE & 2522-9591 \\
\hline PUBLISHER & LLC "Consulting Publishing Company "Business Perspectives" \\
\hline FOUNDER & LLC "Consulting Publishing Company "Business Perspectives" \\
\hline
\end{tabular}

NUMBER OF REFERENCES

34

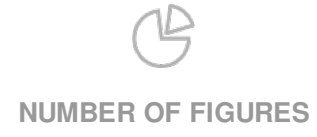

2
NUMBER OF TABLES

4

(C) The author(s) 2022. This publication is an open access article. 


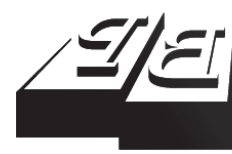

\section{BUSINESS PERSPECTIVES}

(O)

LLC "CPC "Business Perspectives" Hryhorii Skovoroda lane, 10, Sumy, 40022, Ukraine www.businessperspectives.org
Received on: $5^{\text {th }}$ of October, 2020 Accepted on: $23^{\text {rd }}$ of December, 2021 Published on: $28^{\text {th }}$ of December, 2021

(C) Iryna Tsymbaliuk, Nataliia Pavlikha, Olena Zelinska, Alisa Ventsuryk, Anna Radko, 2021

Iryna Tsymbaliuk, Doctor of Economics, Professor, Faculty of Economics and Management, Department of Entrepreneurship and Marketing, Lesya Ukrainka Volyn National University, Ukraine. (Corresponding author)

Nataliia Pavlikha, Doctor of Economics Full Professor, Faculty of International Relations, Department of International Economic Relations, Lesya Ukrainka Volyn National University, Ukraine.

Olena Zelinska, Ph.D. in Economics, Leading Specialist of the Education and Research Department, Lesya Ukrainka Volyn National University, Ukraine.

Alisa Ventsuryk, Ph.D. in Economics, Associate Professor, National

University of Water and Environmental Engineering, Ukraine.

Anna Radko, Senior Lecturer, National University of Water and Environmental Engineering, Ukraine.
This is an Open Access article, distributed under the terms of the Creative Commons Attribution 4.0 International license, which permits unrestricted re-use, distribution, and reproduction in any medium, provided the original work is properly cited.

Conflict of interest statement: Author(s) reported no conflict of interest

Iryna Tsymbaliuk (Ukraine), Nataliia Pavlikha (Ukraine), Olena Zelinska (Ukraine), Alisa Ventsuryk (Ukraine), Anna Radko (Ukraine)

\title{
ASSESSING THE LEVEL OF COMPETITIVENESS OF THE INSURANCE SECTOR DURING ECONOMIC CRISES: THE EXAMPLE OF UKRAINE
}

\begin{abstract}
In the context of the crisis in Ukraine, it is important to increase the competitiveness of the insurance sector as a measure of its stability and dynamism under various scenarios of economic development. The purpose of this paper is to assess the competitiveness of the insurance sector and determine the impact on its level of factors caused by economic crises. Using the method of integrated analysis, the index of competitiveness of the insurance industry is built, which considers the number of businesses, employment, sales, capital investment in the industry, insurance sector performance, share of profitable enterprises, and profitability of the insurance sector in Ukraine for 2012-2020. The results showed that the impact of the 2014-2015 crisis due to endogenous factors, namely political instability in the country and the devaluation of the hryvnia, led to a significant reduction in the competitiveness index of the insurance sector. At the same time, during the pandemic, the insurance sector is stabilized, as evidenced by the growth of sales and the share of profitable enterprises, as well as increasing profitability of insurance activities. The competitiveness index did not change significantly during the pandemic. To analyze the dependence of the integrated indicator of the competitiveness of the insurance sector on economic fluctuations during the crisis, regression equations are constructed. It is proved that the greatest impact on the competitiveness index of the insurance sector in times of crisis is exerted by changes in employment and the amount of capital investment.
\end{abstract}

\section{Keywords}

JEL Classification

\section{INTRODUCTION}

The insurance sector as an integral part of the financial market is a kind of financial stabilizer of market relations, which creates the basis for sustainable economic growth and provides compensation for disasters, catastrophes and other unforeseen events that adversely affect the welfare of the population, businesses and states.

In recent years, Ukraine's insurance industry has reached a certain level of competitiveness and is represented by leading transnational insurance groups from Austria, Belgium, Britain, Israel, the Netherlands, Germany, Poland, Russia, Slovenia, USA, France, Sweden, but has not yet become a factor in national stability of economics (Ruda, 2020). The reason for this is the difficult political situation and the crisis in the economy, which reduces the level of competitiveness and financial stability of sectors of the national economy. In Ukraine, the insurance market remains insignificant in terms of assets and consumption of insurance services, lagging far behind Europe, the United States and other developed countries. In particular, the ratio of insurance premi- 
ums to GDP in Ukraine is 1.4\%. For comparison, in Europe - 5.0\%, the world average - 6.1\%. Among the 88 countries surveyed by the Swiss Re Institute, Ukraine ranks 73rd in terms of consumption of non-life insurance services and 82nd in terms of life insurance services (National Bank of Ukraine, 2020). This necessitates a study of the competitiveness of Ukraine's insurance sector to find competitive advantages and increase its level.

The modern insurance sector is formed under the influence of basic macroeconomic indicators, including gross domestic product, national currency exchange rate, income level, volume of attracted capital investment, etc., which are sensitive to changes in the economic situation in the country and the crisis. Timely identified consequences of the impact of certain crisis phenomena on the functioning of the insurance industry provide grounds to justify competitive advantages and additional opportunities for the development of various areas of insurance activity in Ukraine. This is especially true for research of the functioning of the insurance industry during a post-pandemic crisis, the results of which are valuable for the timely adaptation of insurance activities to changes in the external environment.

\section{LITERATURE REVIEW}

The competitiveness of the industry is revealed in a study by Borysova (2011). She notes that "the competitiveness of the industry is part of the multilevel economic category" competitiveness "along with the competitiveness of the product, enterprise, region, national economy". The features of ensuring competitiveness in certain areas of activity are revealed in the studies by Tryhuba et al. (2019), Yakubiv et al. (2019), and Yao et al. (2019), who studied the system of indices for assessing the competitiveness of China's financial industry. Singh and Kumar (2020) and Fernández et al. (2021) studied the competitiveness of individual industries. The studies show that different areas of activity have their own specifics, which take into account the ability to withstand crises and ensure the stability of economic entities in these industries. Salameh (2021) argues that "insurance firms are known to have unique financial failure characteristics that affect the financial environment of the countries".

The competitive environment of the insurance market was studied by Boiko (2012), who argued that insurance companies play an important role in stimulating the economic activity of market participants, which creates a competitive environment that causes a strong psychological motivation for their economic activity. First of all, insurance creates equal rights for all participants, the opportunity to benefit provides confidence in business development. Vnukova and Mamedova (2020) examined the specifics of managing the competitiveness of insurance companies and the need to study the relationship of competitiveness with other concepts of competition theory, in particular, competitiveness of service (product), attractiveness of service (product), competitive advantage, competitive position, competitive potential, competitive strategy.

Nalukova (2016) defines competition in the field of insurance as "a type of interaction between insurers in order to get the most advantageous position in the market, which will provide the most favorable conditions for the sale of insurance products and insurance business, and will benefit in this competitive environment."

Ponomareva (2017), Rekunenko and Vidmenko (2019) assessed the competitiveness of insurance companies in the current conditions of economic transformation and analyzed the factors that shape the competitive environment of insurance companies. The scientists studied the peculiarities of the insurance market in the changing economic environment of Ukraine and determined the criteria for the competitiveness of insurance companies.

The subject of research of many scientists is also to reveal the essence of crises and their impact on economic development. In particular, Berzon (2020) stated the theoretical foundations of the concept of "socio-economic crisis". The content of financial and banking crises is described by Ukrainian scientists (Pavlikha et al., 2009; Pavlikha \& Ius, 2012); the impact of global crises on the state of 
Ukraine's economy is analyzed, and the ways to overcome them are substantiated (Melnyk, 2014; Pavlikha \& Humeniuk, 2010). Pavlikha and Humeniuk (2010) considered the impact of the global financial crisis on the development of Ukraine's economy. Shataylo (2019) classified the crises of socio-economic systems. Ashraf et al. (2020) investigated the role of deposit insurance in reducing banking risks in both normal and crisis periods. Kuznichenko et al. (2021) argue that "the creation of deposit insurance systems in world practice has become a tool for solving problems of maintaining the stability of banking systems, increasing customer confidence in banks and other credit institutions, and preventing cases of mass withdrawal of deposits during economic crises."

Within the crisis caused by the COVID 19 pandemic, the attention of scientists is drawn to the problems of the financial sector in crisis. In particular, Davymuk and Fedulov (2020) studied the practices of the world and Ukraine to support business and citizens during economic crises, including the crisis caused by the COVID-19 pandemic. Orlov (2020) studied the directions of ensuring product quality and competitiveness of enterprises in times of crisis, as well as the impact of crises on all spheres of management.

Prokopjeva et al. (2021) highlighted that "behavioral characteristics attributed to consumers of insurance services are a relevant factor for analyzing the current situation in the insurance market and developing effective strategies for insurers' actions. In turn, considering these characteristics allows an insurer to be more successful in the highly competitive field, achieving mutual satisfaction in interacting with the customer".

The COVID-19 pandemic has revolutionized the insurance business model. The first attempts to study and analyze the short-term impact of COVID-19 on insurance activities were made by Stojkoski et al. (2021) on the example of a separate country - Northern Macedonia. Volosovych et al. (2021) summarized the transformation of the institutional environment of insurance in the COVID-19 pandemic and identified prospects for its development in the post-pandemic period. Shevchuk et al. (2020) studied the dynamics of changes in the Ukrainian insurance market dur- ing the quarantine period and identified the main technological achievements of leading insurers. At the same time, the complexity of the insurance industry is due to the impact of constant crises of various types, which necessitates an in-depth study of the insurance industry competitiveness in times of economic instability. However, today in Ukraine there are no comprehensive studies that assess the competitiveness of the insurance sector and determine the impact of economic crises on the level of competitiveness of the insurance sector.

\section{AIMS}

The aim of the study is to assess the competitiveness of the insurance sector and determine the impact on its level of factors caused by economic crises.

\section{METHODS}

The following methods were used in the study: statistical and integrated analysis - to calculate the index of competitiveness of the insurance sector; modeling and correlation-regression analysis - to determine the impact of indicators of economic crises on the level of competitiveness of the insurance sector.

By deriving the competitiveness index of the insurance sector, indicators were selected to most accurately reflect the level of insurance sector competitiveness in conditions of economic instability. All indicators that form the competitiveness index are measured using different physical quantities and vary in different ranges, so they were rationed. This made it possible to bring the indicators to a standardized form.

All selected indicators are stimulants, so there is a direct relationship with the competitiveness index of the insurance sector - the greater the value of an individual indicator, the higher the competitiveness level of the insurance sector. Therefore, the following formula was used for rationing:

$$
I_{j}=\frac{X_{j}-X_{\min }}{X_{\max }-X_{\min }}
$$


where $I_{j}$ - is the normalized value of $j$ indicator, $X_{\min }$ - minimum value of $j$ indicator, and $X_{\max }$ maximum value of $j$ indicator.

Such normalization provides information unidirectionality of indicators, while their values change in the range from 0 to 1 . The indicators providing the lowest level of competitiveness will correspond to numerical values close to 0 , and the best ones will approach 1 .

The integral index of the competitiveness in the insurance sector is calculated as follows:

$$
I_{\text {competitiv_insur }}^{\text {integral__ }}=\frac{\sum_{j=1}^{n} I_{j}}{n},
$$

where $n$ - the number of indicators taken into account in the competitiveness of the insurance industry.

When determining the influence of the main macroeconomic indicators, which are indicators of the onset of crises, on the level of competitiveness of the insurance industry, correlation and regression analysis tools were used and the corresponding regression equations were constructed:

$$
y=b_{0}+b_{1} x_{3},
$$

where $y$ - the resulting indicator, which is the index of competitiveness of the insurance industry; $x_{\mathrm{i}}$ - the independent indicator of economic crises; $b_{1}$ - regression coefficient; $b_{0}$ - the value that determines that impact on the resulting indicator of other factors not taken into account in the equation.

To determine the closeness of the relationship between the indicators of economic crises and the competitiveness index, the coefficient of determination was used $\left(\mathrm{R}^{2}\right)$, which characterizes the extent to which the variation of the dependent variable is determined by the variation of the independent variables.

The Chaddock Scale was used to qualitatively estimate the correlation tightness by the correlation coefficient.
Table 1. Chaddock's scale

\begin{tabular}{c|c}
\hline $\begin{array}{c}\text { Coefficient } \\
\text { of determination } \mathbf{( R}^{\mathbf{2}} \mathbf{)}\end{array}$ & $\begin{array}{c}\text { Qualitative characteristic } \\
\text { of the tightness of connection }\end{array}$ \\
\hline $0.1-0.3$ & Weak \\
\hline $0.3-0.5$ & Moderate \\
\hline $0.5-0.7$ & Moderate \\
\hline $0.7-0.9$ & Strong \\
\hline $0.9-0.99$ & Very strong \\
\hline
\end{tabular}

\section{RESULTS}

Insurance is a sector, which is represented as a set of industries and different activity types, the functional purpose of which in the system of social production is expressed in the creation and sale of insurance services. Characterizing the problems of managing the competitiveness of insurance in Ukraine, it should be noted that insurance activities have long functioned in economic, political and post-pandemic crises, fighting in eastern Ukraine, declining solvency, devaluation of the national currency, rising inflation, etc.

As a result, small insurance companies cannot withstand the effects of the crisis, their number is declining. This is due to the instability of the economic and political situation in the country, as well as "relatively low level of capitalization of insurance companies in their number and insufficient supply of quality insurance products" (Rekunenko \& Vidmenko, 2019).

Analysis of research on the nature of competitiveness gives grounds to define the competitiveness of economic relations as the presence of competitive advantages of entities that allow flexible response to the negative effects of crises and environmental changes, ensuring profitability of economic entities in this area. The competitiveness of the sphere of economic relations forms the competitiveness of the national economy and is determined by the competitiveness level of enterprises and industries that shape it.

The main determinants of the competitiveness of the insurance sector are factor conditions (human and information resources, insurance capital, infrastructure); conditions of domestic demand in the insurance market (structure of demand, compliance with trends in the development of demand 
in the world market, trends in the volume of demand); related and service industries (presence or absence of industries related to insurance activities); strategy and structure of insurance companies, competition between them, etc.

In the context of researching the competitiveness of the insurance sector under the influence of crises, it is appropriate to choose those parameters of industry development that are sensitive to economic fluctuations. This study proposes to select indicators such as the number of operating business entities as indicators of insurance competitiveness; number of employees in business entities; volume of products sold; capital investments of enterprises; net profit (loss) of enterprises; the share of profitable enterprises; the level of profitability (loss) of enterprises' operating activities (Table 2).

The economic crisis of 2008-2009 significantly affected the insurance market due to the unstable situation in the financial market, declining solvency of the population, its confidence in the financial sector. This has led to a decrease in demand for insurance services, deteriorating conditions for investing assets and reducing the financial reliability of insurance companies, strengthening the negative trends in the dynamics of domestic insurance in general.

The systemic banking crisis of 2014-2016 also contributed to this, "since deposit accounts in banks are a source of insurance reserves, which has hit the insurers in fulfilling their obligations" (Ekonomichna Pravda, 2017).

Analysis of the development of insurance activities in Ukraine in the period 2013-2015 revealed a decrease in its activity. The reasons for this are the aggravation of the crisis situation in the eastern Ukrainian military conflict, the instability of the financial situation, the imperfection of the institutional and legal support in the insurance sector, which significantly affected the reduction of its competitiveness. In general, the crisis of 20142015 had a negative impact, led to a decrease in the sector competitiveness and to a reduction in insurance activity (Figure 1).

Table 2. Main indicators of the competitiveness of the insurance sector in Ukraine

Source: Compiled and calculated according to official requests to the State Statistics Service of Ukraine (2021).

\begin{tabular}{|c|c|c|c|c|c|c|c|}
\hline Years & $\begin{array}{l}\text { Number of } \\
\text { operating } \\
\text { business } \\
\text { entities, } \\
\text { units }\end{array}$ & $\begin{array}{c}\text { Number of } \\
\text { employees } \\
\text { in business } \\
\text { entities, } \\
\text { number of } \\
\text { employees }\end{array}$ & $\begin{array}{l}\text { Volume } \\
\text { of sold } \\
\text { products, } \\
\text { in thousand } \\
\text { USD }\end{array}$ & $\begin{array}{c}\text { Capital } \\
\text { investment } \\
\text { of } \\
\text { enterprises, } \\
\text { in \% of all } \\
\text { activities } \\
\end{array}$ & $\begin{array}{l}\text { Net profit } \\
\text { (loss) of } \\
\text { enterprises, } \\
\text { in thousand } \\
\text { USD }\end{array}$ & $\begin{array}{c}\text { Share of } \\
\text { profitable } \\
\text { enterprises in } \\
\% \text { to the total } \\
\text { number of } \\
\text { enterprises in \% }\end{array}$ & $\begin{array}{c}\text { Profitability } \\
\text { (loss) of } \\
\text { operating } \\
\text { activities of } \\
\text { enterprises, \% }\end{array}$ \\
\hline 2012 & 789 & 32784 & 2205627 & 0.174 & 646832 & 69.838 & 37.040 \\
\hline 2013 & 750 & 28307 & 2562029 & 0.123 & 671203 & 70.880 & 41.922 \\
\hline 2014 & 792 & 28897 & 1312837 & 0.216 & 54677 & 72.289 & -0.026 \\
\hline 2015 & 975 & 24380 & 785049 & 0.149 & -42892 & 60.156 & -4.951 \\
\hline 2016 & 866 & 23878 & 815001 & 0.114 & 19082 & 65.607 & -2.020 \\
\hline 2017 & 672 & 20490 & 919146 & 0.096 & -12133 & 62.538 & -0.187 \\
\hline 2018 & 561 & 19500 & 1061396 & 0.086 & 7017 & 63.975 & -0.148 \\
\hline 2019 & 539 & 18063 & 1317497 & 0.105 & 52626 & 71.186 & 1.912 \\
\hline 2020 & 463 & 17607 & 1312612 & 0.106 & 96974 & 71.691 & 3.027 \\
\hline \multicolumn{8}{|c|}{ Normalized data } \\
\hline 2012 & 0.637 & 1.000 & 0.799 & 0.676 & 0.966 & 0.798 & 0.896 \\
\hline 2013 & 0.561 & 0.705 & 1.000 & 0.289 & 1.000 & 0.884 & 1.000 \\
\hline 2014 & 0.643 & 0.744 & 0.297 & 1.000 & 0.137 & 1.000 & 0.105 \\
\hline 2015 & 1.000 & 0.446 & 0.000 & 0.107 & 0.000 & 0.000 & 0.000 \\
\hline 2016 & 0.787 & 0.413 & 0.017 & 0.048 & 0.087 & 0.449 & 0.063 \\
\hline 2017 & 0.408 & 0.190 & 0.075 & 0.012 & 0.043 & 0.196 & 0.102 \\
\hline 2018 & 0.191 & 0.125 & 0.156 & 0.000 & 0.070 & 0.315 & 0.102 \\
\hline 2019 & 0.148 & 0.030 & 0.300 & 0.060 & 0.134 & 0.909 & 0.146 \\
\hline 2020 & 0.000 & 0.000 & 0.297 & 0.096 & 0.196 & 0.951 & 0.170 \\
\hline
\end{tabular}




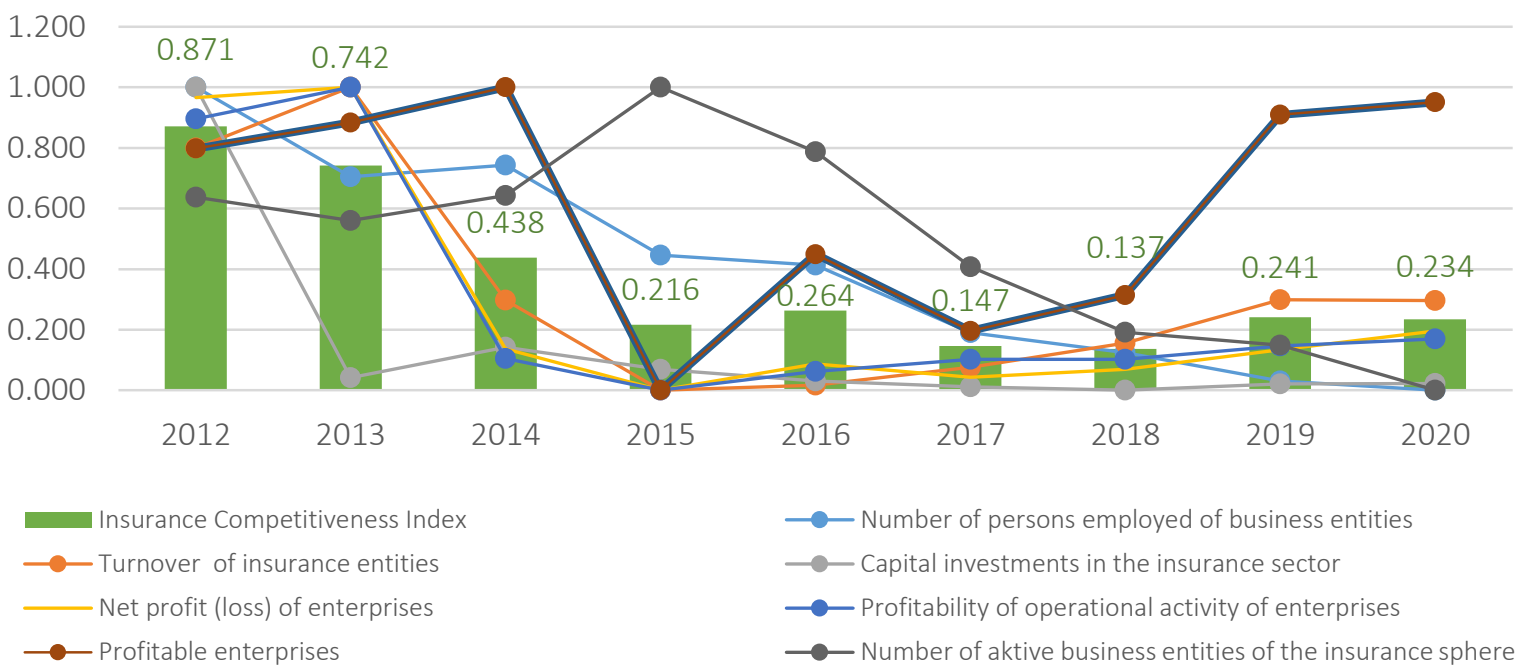

Figure 1. Dynamics of the competitiveness level of insurance in Ukraine in crisis

It should be noted that in 2014-2015, the real testing for the Ukrainian insurance market was the increase in unprofitability associated with more than two-fold devaluation of the hryvnia against the US dollar, which has led to the need to revise some insurance conditions and more conservative risk assessments of insurance risks (Legislation of Ukraine, 2015).

In turn, the coronavirus pandemic in the world has significantly affected insurance activities both directly and through underwriting risks. The increase in mortality and morbidity from COVID-19 as a threat to human life, in order to ensure confidence in their own future and the future of their descendants, has led to the need for life insurance. As a result, the volume of income from life insurance is growing, which has resulted in increased profitability and competitiveness of the insurance industry. Insurance agents, insurance companies and brokers have actively responded to the pandemic crisis in many sectors of the insurance market.

As can be seen, the crisis caused by the pandemic did not have such negative consequences as the previous crises. On the contrary, there is a slight increase in the volume of products sold. It should also be noted that the net profit of insurance companies during the coronavirus crisis has almost doubled. The increase in the share of enterprises that kept profits during this pe- riod was mainly due to the general reduction in the number of economic entities. The decrease in the number of unprofitable enterprises led to an overall increase in the average profitability of insurance activities.

Based on the selected indicators that reflect the state of the insurance industry competitiveness in times of crisis, an integral competitiveness index of insurance activities was built (Table 3).

To identify the dependence degree of the integrated indicator of the competitiveness in the insurance sector on the change of the main indicators that characterize economic fluctuations in crisis, the tools of economic and mathematical analysis were used (Table 4). The constructed regression equations and the calculated indicators of determination made it possible to establish that the level of employment in the country has the greatest influence. The coefficient of determination $\mathrm{R}^{2}=$ 0.957 is the highest and, on the Chaddock scale, indicates a high level of correlation between the factor and the resulting indicator, which is the competitiveness of the sector. The increase in economic activity contributes to the development of the insurance sector. At the same time, it is this indicator in the period of crises characterized by an increase in unemployment that can cause the curtailment of activities in the field of insurance services and a decrease in the competitiveness level of the industry. 
Table 3. Integral index and factors of competitiveness of the insurance sector in Ukraine

\begin{tabular}{|c|c|c|c|c|c|}
\hline \multirow[b]{2}{*}{ Years } & \multirow[b]{2}{*}{$\begin{array}{c}\text { Insurance sector } \\
\text { competitiveness } \\
\text { index }\end{array}$} & \multicolumn{4}{|c|}{ Indicators of the economic crisis } \\
\hline & & $\begin{array}{l}\text { GDP at actual prices, } \\
\text { million USD }\end{array}$ & $\begin{array}{c}\text { Disposable income per } \\
\text { capita, USD }\end{array}$ & $\begin{array}{c}\text { Capital Investments / } \\
\text { thsd USD }\end{array}$ & $\begin{array}{c}\text { People } \\
\text { employed, } \\
\text { thsd }\end{array}$ \\
\hline 2012 & 0.871 & 175803 & 3154.7 & 50589.5 & 19261.4 \\
\hline 2013 & 0.742 & 183379 & 3344.1 & 33654.3 & 19314.2 \\
\hline 2014 & 0.438 & 133466 & 2252.49 & 32829.0 & 18073.3 \\
\hline 2015 & 0.216 & 91051 & 1456.19 & 14844.5 & 16443.2 \\
\hline 2016 & 0.264 & 93361 & 1451.27 & 12726.2 & 16276.9 \\
\hline 2017 & 0.147 & 112076 & 1777.06 & 13215.2 & 16156.4 \\
\hline 2018 & 0.137 & 130942 & 2149.39 & 15421.1 & 16360.9 \\
\hline 2019 & 0.241 & 153857 & 2674.66 & 21718.4 & 16578.3 \\
\hline 2020 & 0.234 & 155485 & 2720.88 & 16021.1 & 15915.3 \\
\hline
\end{tabular}

Table 4. Influence of economic factors on the competitiveness of the insurance sector

\begin{tabular}{|c|c|c|c|}
\hline $\begin{array}{l}\text { Competitiveness factors of the } \\
\text { insurance sector }\end{array}$ & Regression equation & $\begin{array}{l}\text { Coefficient of } \\
\text { determination }\end{array}$ & Type of connection \\
\hline GDP at actual prices & $y=6 \mathrm{E}-06 x-0.402$ & $R^{2}=0.498$ & Weak \\
\hline Disposable income per capita & $y=0.000 x-0.286$ & $R^{2}=0.532$ & Moderate \\
\hline Capital Investments & $y=2 E-05 x-0.085$ & $R^{2}=0.877$ & Strong \\
\hline Employment rate & $y=6 \mathrm{E}-08 x^{2}-0.001 x+14.93$ & $R^{2}=0.957$ & Very strong \\
\hline
\end{tabular}

The volume of investments in the investment sphere also has a strong influence. At the same time, it is one of the indicators that react sharply to economic fluctuations. Thus, during crises, the volume of capital investment has significantly decreased, negatively affecting the overall competitiveness of the industry. It should be noted that the response was delayed, in particular during the 2014-2015 crisis the decrease in investments occurred only in 2015, when the volume of investments decreased compared to 2014 by $54.8 \%$. During the second crisis, investment also reacted to significant cuts. In 2020, compared to 2019 , the volume of capital investments attracted to Ukraine's insurance sector decreased by $40.8 \%$, decreasing from USD 21718.4 to 16021.1 ths, respectively. Given the experience of the 2014-2015 crisis, when the main drop in the volume of investments occurred during the second year, it can be assumed that in 2021 investments in the insurance sector will continue to decline.

The insignificant influence of the available income can be explained by the general low level of income among the population, which is not sufficient for making savings and reduces the level of expenses for the purchase of insurance servic- es. Low income in general is one of the key factors hindering the development of insurance in Ukraine. Therefore, fluctuations in the general level of household income do not significantly affect the competitiveness of the industry.

The lowest level of correlation is observed between the competitiveness level in the insurance sector and the country's GDP. This is due to the fact that insurance occupies a rather small share in the national economy structure, as well as atypical trends in the industry during the last crisis. In particular, with a simultaneous reduction in the number of people employed, the profits of insurance business entities increased.

Figure 2 graphically displays the dependence of the integral indicator on the main indicators of economic crises.

It should be noted that the insurance competitiveness in Ukraine depends on the combination of both macroeconomic and domestic factors. Their analysis in the conditions of crisis phenomena is important for the formation of a balanced insurance portfolio, as well as substantiation of the role of the underwriting process in ensuring the 

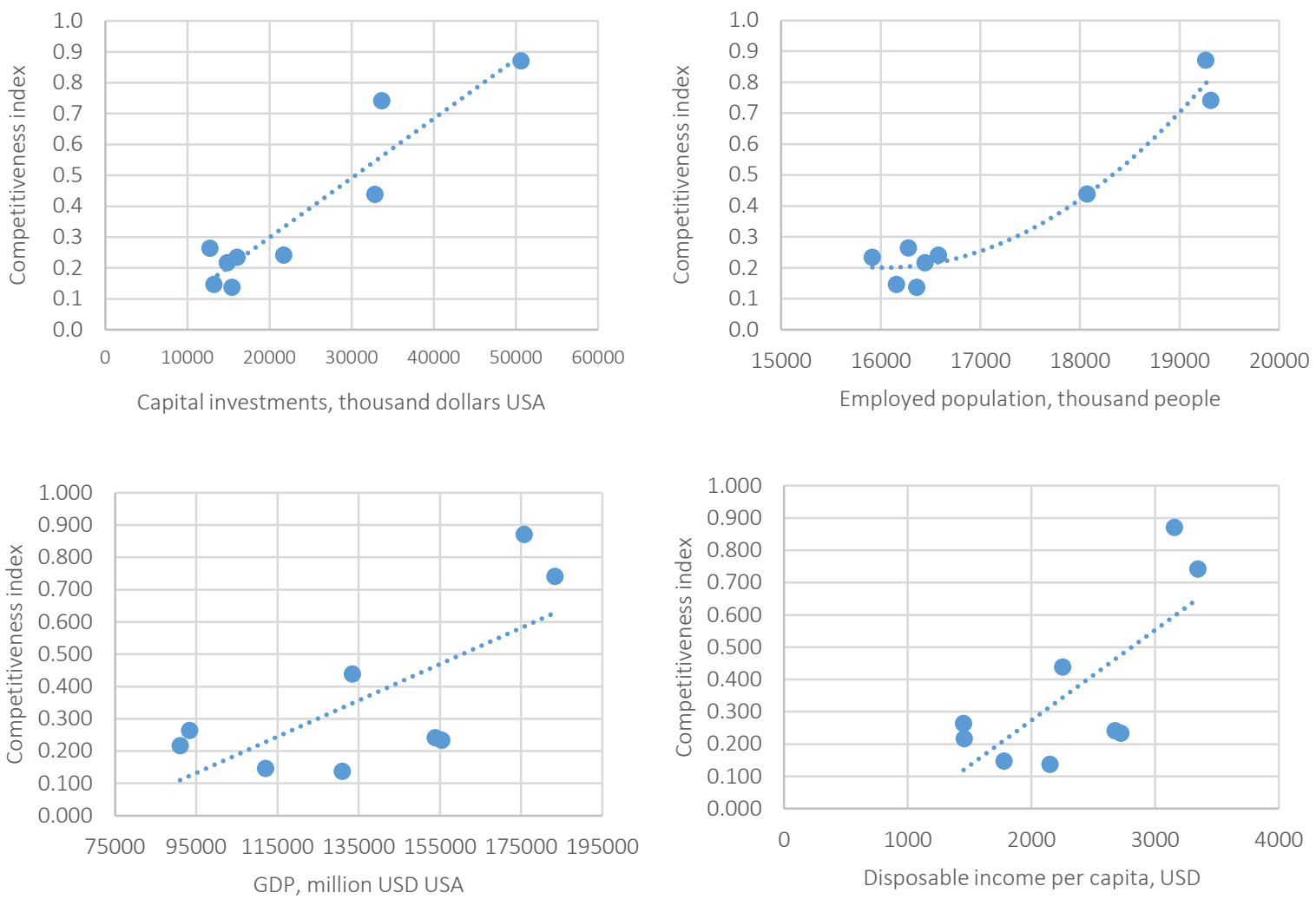

Figure 2. Correlation of the main economic crises indicators and the competitiveness index of insurance activities

intensification of the development of insurance activities in the country. Agreeing with the opinion of scientists involved in the development of the Ukrainian insurance sector (Panchuk, 2018), it can be noted that to strengthen competitive positions, it is necessary to build up insurance reserves, increase the quality and size of assets in order to fulfill their obligations to policyholders, conduct a comprehensive risk assessment to develop perfect insurance products. It should be noted that today Ukrainian insurance companies have significant development potential, which is not fully realized. Compared to the highly developed countries, the insurance business in Ukraine needs to strengthen its competitive position in the global insurance market.

\section{CONCLUSIONS}

To calculate the index of competitiveness of the insurance sector in Ukraine, standardized data on changes in the number of business entities, employees, sales, capital investment, the share of profitable enterprises, the level of profitability were used. The analysis showed that the index of competitiveness of the insurance sector was significantly affected by the economic crisis of 20142015. The decline in the number of businesses, employment, and capital investment is the result of political instability and the devaluation of the hryvnia. During this period, the decline in the competitiveness index was most affected by the reduction in the number of profitable enterprises in the industry, whose share was only $60 \%$. Further fluctuations in the competitiveness index were insignificant. The crisis related to the COVID-2019 pandemic has had a moderate impact on insurance. In 2020, there was a reduction in the number of existing businesses, but the efficiency of their activities increased. 
The constructed regression equations and the calculated indicators of determination made it possible to establish the impact of changes in the main indicators characterizing economic fluctuations during crises on the level of the integrated indicator of insurance competitiveness. It was found that the level of employment in the country and the volume of capital investment is a key factor in increasing the competitiveness of the insurance industry.

Since the results of the calculations showed a decrease in the level of competitiveness of insurance services in Ukraine under the influence of the economic crisis of 2014-2015, the prospects for further research will be related to the development of anti-crisis regulation of insurance and strengthening its competitive advantage.

\section{AUTHOR CONTRIBUTIONS}

Conceptualization: Iryna Tsymbaliuk.

Datacuration: Olena Zelinska.

Formalanalysis: Olena Zelinska, Anna Radko, Alisa Ventsuryk.

Investigation: Iryna Tsymbaliuk, Nataliia Pavlikha, Olena Zelinska, Anna Radko, Alisa Ventsuryk. Methodology: Iryna Tsymbaliuk, Nataliia Pavlikha.

Projectadministration: Iryna Tsymbaliuk, Nataliia Pavlikha.

Supervision: Iryna Tsymbaliuk.

Validation: Iryna Tsymbaliuk, Nataliia Pavlikha, Olena Zelinska, Anna Radko, Alisa Ventsuryk.

Visualization: Olena Zelinska, Anna Radko, Alisa Ventsuryk.

Writing - originaldraft: Iryna Tsymbaliuk, Nataliia Pavlikha, Anna Radko, Alisa Ventsuryk.

Writing - review \& editing: Nataliia Pavlikha.

\section{REFERENCES}

1. Ashraf, B., Zheng, C., Jiang, C., \& Qian, N. (2020). Capital regulation, deposit insurance and bank risk: International evidence from normal and crisis periods. Research in International Business and Finance, 52, 101188. https://doi. org/10.1016/j.ribaf.2020.101188

2. Berzon, S. (2020). Teoretychni zasady formuvannia poniattia "sotsialno-ekonomichna kryza" [Theoretical principles of forming the concept of "socio-economic crisis"]. Nobelivskyi visnyk - Nobel Bulletin, 1, 6-14. (In Ukrainian). Retrieved from http://nbuv.gov.ua/ UJRN/bmef_2020_1_3

3. Boiko, L. (2012). Problemni pytannia rozvytku strakhovoho rynku Ukrainy [Problematic issues of development of the insurance market of Ukraine]. Visnyk Sotsialno-Ekonomichnykh Doslidzhen - Bulletin of Socio-Economic Research, 3(2), 137-143. (In Ukrainian). Retrieved from http://dspace.oneu.edu.ua/ jspui/handle/123456789/512
4. Borysova, T. M. (2011). Konkurentospromozhnist haluzi: determinanty formuvannia ta suchasni metody otsiniuvannia [Competitiveness of the industry: determinants of formation and modern evaluation methods]. Visnyk Khmelnytskoho Natsionalnoho Universytetu Bulletin of Khmelnytsky National University, 6(1), 56-60. (In Ukrainian).

5. Davymuka, S., \& Fedulova, L. (2020). Ekonomichna kryza, obumovlena pandemiieiu COVID-19: peredbachennia, prohnozy, zakhody pom'iakshennia [The economic crisis caused by the COVID-19 pandemic: predictions, forecasts, mitigation measures]. Rehionalna Ekonomika - Regional Economy, 4, 93-105. (In Ukrainian). Retrieved from http://nbuv. gov.ua/UJRN/regek_2020_4_14

6. Ekonomichna Pravda. (2017). Vtraty ekonomiky vid bankivskoi kryzy v 2014-2016 rr. - 38\% VVP [Economic losses from the banking crisis in 2014-2016 - 38\% of GDP]. (In Ukrainian). Retrieved from https://www.epravda.com.ua/ news/2017/07/5/626764/

7. Fernández, J., Martínez, J., \& Martín, J. (2021). An analysis of the competitiveness of the tourism industry in a context of economic recovery following the COVID19 pandemic. Technological Forecasting and Social Change, 174, 121301. https://doi.org/10.1016/j. techfore.2021.121301

8. Fu, Y., He, W., \& Hao, R. (2019). Comparative Analysis of Financial Industry Competitiveness of Regions in China. Journal of Scientific and Industrial Research (JSIR), 78(1), 11-14. Retrieved from http://nopr.niscair.res.in/ handle/123456789/45699

9. Kuznichenko, P., Frolov, S., Orlov, V., \& Boiko, O. (2021). European Deposit Insurance Scheme implementation: pros and cons. Banks and Bank Systems, 16(1), 116126. https://dx.doi.org/10.21511/ bbs.16(1).2021.11 
10. Legislation of Ukraine. (2015). Kompleksna prohrama rozvytku finansovoho sektoru Ukrainy do 2020 roku: Postanova Pravlinnia Natsionalnoho banku Ukrainy vid 18.06. 2015. № 391. [Comprehensive program for the development of the financial sector of Ukraine until 2020: Resolution of the Board of the National Bank of Ukraine of 18.06. 2015]. (In Ukrainian). Retrieved from https://zakon.rada.gov.ua/ laws/show/v0391500-15\#Text

11. Melnyk, A. (2014). The global economic crisis in the Ukrainian economy and their consequences. Hlobalni ta Natsionalni Problemy Ekonomiky - Global and National Economic Problems, 2, 108-113. (In Ukrainian). Retrieved from http://global-national.in.ua/archive/2-2014/22.pdf

12. Nalukova, N. (2016). Konkurentsiia yak zaporuka uspishnoho rozvytku strakhovoho rynku. [Competition as a guarantee of successful development of the insurance market]. Svit finansiv - The World of Finance, 3(48), 102-112. (In Ukrainian). Retrieved from http://sf.wunu.edu.ua/index. $\mathrm{php} / \mathrm{sf} /$ article/view/956

13. National Bank of Ukraine. (2020). Bila knyha Maibutnie rehuliuvannia rynku strakhuvannia $v$ Ukraini [White Paper on Insurance Market Regulation Prospects in Ukraine]. (In Ukrainian). Retrieved from https://bank.gov.ua/admin_uploads/article/White_paper_insurance_2020.pdf

14. Orlov, P. A. (2020). Svitova ekonomichna kryza i pandemiia COVID-19 ta yikh uroky dlia uriadu krain [The global economic crisis and the COVID-19 pandemic and their lessons for governments]. Biznes Inform - Business Inform, 6 , 30-40. (In Ukrainian). Retrieved from http://nbuv.gov.ua/UJRN/ binf_2020_6_5

15. Panchuk, D., \& Kostetskyi, V. (2018). Problemy mainovoho strakhuvannia v Ukraini [Problems of property insurance in Ukraine]. Aktualni problemy korporatyvnykh finansiv ta finansovykh rynkiv: zbirnyk studentskykh naukovykh prats [Current issues of corporate finance and financial markets: a collection of student research papers] (pp. 100-104). (In Ukrainian).

16. Pavlikha, N., \& Humeniuk, D. (2010). Problemy ekonomiky Ukrainy v umovakh svitovoi finansovoi kryzy [Problems of Ukraine's economy in the global financial crisis]. Aktualni problemy finansovoi systemy Ukrainy - Current problems of the financial system of Ukraine: Collection of abstracts, 2, 30-32. Cherkasy: ChSTU. (In Ukrainian).

17. Pavlikha, N., \& Humeniuk, D. (2010). Vplyv svitovoi finansovoi kryzy na rozvytok ekonomiky Ukrainy [The impact of the global financial crisis on the development of Ukraine's economy]. Aktualni problemy mizhnarodnykh ekonomichnykh vidnosyn ta turystychnoho biznesu: Materialy VI naukovo-praktychnoi konferentsii molodykh vchenykh - Current issues of international economic relations and tourism business: Proceedings of the VI scientificpractical conference of young scientists. Kharkiv. (In Ukrainian).

18. Pavlikha, N., \& Ius, I. (2012). Osoblyvosti proiavu svitovoi bankivskoi kryzy ta instrumenty yii zapobihannia [Features of the global banking crisis and tools to prevent it]. Visnyk Lvivskoho universytetu - Bulletin of Lviv University, 31, 309-315. (In Ukrainian).

19. Pavlikha, N., Dedeliuk, K., \& Shokol, V. (2009). Ekonomistymizhnarodnyky pro svitovu finansovu kryzu [International economists on the global financial crisis]. Naukovyi visnyk VNU imeni Lesi Ukrainky. Mizhnarodni vidnosyny - Scientific Bulletin of Lesya Ukrainka University. International relations, 11, 47-50. (In Ukrainian).

20. Pavlikha, N., \& Kytsiuk, I. (2014). Upravlinnia konkurentospromozhnistiu natsionalnoi ekonomiky: rehionalnyi vymir [Managing the competitiveness of the national economy: a regional dimension]. Vezha-Druk. (In Ukrainian).

21. Ponomarova, O., Alieksieieva, L., \& Trystan, V. (2017). Konkurentospromozhnist strakhovykh kompanii v suchasnykh umovakh ekonomichnykh peretvoren

[Competitiveness of insurance companies in modern conditions of economic transformations]. Ekonomika. Finansy. Pravo Economy. Finances. Law, 12, 18-21. (In Ukrainian). Retrieved from http://nbuv.gov.ua/UJRN/ecfipr_2017_12_6

22. Prokopjeva, E., Tankov, E., Shibaeva, T., \& Perekhozheva, E. (2021). Behavioral models in insurance risk management. Investment Management and Financial Innovations, 18(4), 8094. https://dx.doi.org/10.21511/ imfi.18(4).2021.08

23. Rekunenko, I., \& Vidmenko, Yu. (2019). Rozvytok strakhovoho rynku v umovakh minlyvosti ekonomichnoho seredovyshcha Ukrainy [Development of the insurance market in the conditions of variability of the economic environment of Ukraine]. Infrastruktura rynku Market infrastructure, 29, 485. (In Ukrainian).

24. Ruda, O. (2020). Insurance market development in Ukraine. Efektyvna ekonomika - Effective economics, 2. (In Ukrainian). https://dx.doi.org/10.32702/23072105-2020.2.55

25. Salameh, H. M. (2021). Failure threats of insurance companies: A case study of financial environments of Jordan. Investment Management and Financial Innovations, 18(3), 113-126. https://dx.doi. org/10.21511/imfi.18(3).2021.11

26. Shatailo, O. (2019). Kryzy sotsialno-ekonomichnykh system: proiavy ta oznaky [Crises of socioeconomic systems: manifestations and signs]. Visnyk Kyivskoho natsionalnoho torhovelno-ekonomichnoho universytetu - Bulletin of the Kyiv National University of Trade and Economics, 2, 91102. (In Ukrainian). Retrieved from http://nbuv.gov.ua/UJRN/ Vknteu_2019_2_8

27. Shevchuk, O., Kondrat, I., \& Stanienda, J. (2020). Pandemic as an accelerator of digital transformation in the insurance industry: evidence from Ukraine. Insurance 
Markets and Companies, 11(1), 30-41. https://dx.doi.org/10.21511/ ins.11(1).2020.04

28. Singh, R., \& Kumar, R. (2020) A case-based analysis of the competitiveness of the North Indian sugar industry. Global Business and Organizational Exellence, 40(1), 6-18. https://doi.org/10.1002/joe.22060

29. State Statistics Service of Ukraine. (2021). Official site. (In Ukrainian). Retrieved from http://www. ukrstat.gov.ua/

30. Stojkoski, V., Jolakoski, P., \& Ivanovski, I. (2021). The short-run impact of COVID-19 on the activity in the insurance industry in the Republic of North Macedonia. Risk Management and Insurance Review, 24(3), 221-242. https://doi. org/10.1111/rmir. 12187
31. Tryhuba, A., Pavlikha, N., Rudynets, M., Tryhuba, I., Grabovets, V., Skalyga, M., Tsymbaliuk, I., Khomiuk, N., \& Fedorchuk-Moroz, V. (2019). Studying the influence of production conditions on the content of operations in logistic systems of milk collection. Eastern-European Journal of Enterprise Technologies, 3(99), 50-63. https://doi.org/10.15587/17294061.2019.171052

32. Vnukova, N., \& Mamedova, E. (2020). Teoretychni aspekty vyznachennia sutnosti konkurentospromozhnosti strakhovykh kompanii [Theoretical aspects of determining the essence of the competitiveness of insurance companies]. Efektyvna ekonomi- ka - Efficient economy, 4. https:// doi.org/10.32702/2307-21052020.4 .12

33. Volosovych, S., Zelenitsa, I., Kondratenko, D., Szymla, W., \& Mamchur, R. (2021). Transformation of insurance technologies in the context of a pandemic. Insurance Markets and Companies, 12(1), 1-13. https://dx.doi. org/10.21511/ins.12(1).2021.01

34. Yakubiv, V., Sodoma, R. Hrytsyna, O. Pavlikha, N. Shmatkovska, T. Tsymbaliuk, I. Marcus, O., \& Brodska, I. (2019). Development of electronic banking: a case study of Ukraine. Entrepreneurship and Sustainability, 7(1), 219232. (In Ukrainian). http://doi. org/10.9770/jesi.2019.7.1(17) 